\title{
Diameter of the Larger Follicle at the Moment of the Estradiol Application and the Gestation Rate in Cows Submitted to Artificial Insemination at Fixed Time
}

\author{
Emílio Pereira de Brito Neto', Rafael Otero², Darwin Hernández ${ }^{2 *}$, \\ Eduardo Paulino da Costa ${ }^{1}$ and Ademir Moraes Ferreira ${ }^{3}$ \\ 'Universidade Federal de Viçosa, Viçosa - MG, 36570-900, Brasil; emilionetovet@yahoo.com.br, epcosta@ufv.br, \\ 2Universidad de Sucre, Campus Ciencias Agropecuarias, Sincelejo, Sucre, \\ Colombia; rafael.otero@unisucre.edu.co,darwin.hernandez@unisucre.edu.co, \\ 3Embrapa Gado de Leite, Juiz de Fora - MG, 36038-330, Brasil; ademirferreira9@yahoo.com.br
}

\begin{abstract}
Objective: This study was conducted to evaluate the effect of the follicular diameter upon gestation rate of cows submitted to Artificial Insemination at Fixed Time (IATF). Methods: Forty-seven crossbred cows Bos taurus $x$ indicus presenting cyclical luteal ovarian activity and under nursing were used. The cows were given $150 \mu \mathrm{g}$ of $\mathrm{PGF}_{2 \alpha}$ via Intra-Muscular (IM). The diameter of the present largest follicle was measured through Ultra-Sound Examination (USE). After 24 hours, the cows were given $2 \mu \mathrm{g}$ of estradiol via IM and they were again evaluated through USE for certification of the follicular dominance. Later, they were divided into two treatments: treatment 1 (cows with dominant follicle $<13 \mathrm{~mm}$ ) and treatment 2 (cows with dominant follicle $\geq 13 \mathrm{~mm}$ ). After 48 hours from the application of $E_{2}$, the cows were Artificially Inseminated (AI). However, those cows presenting estrus in advance were inseminated at 12 hours after manifestation of the same one. Ten days after AI the concentration of progesterone (P4) was quantified by radioimmunoassay using a commercial kit. The gestation diagnosis was accomplished at 30 and 100 days after IA through USE. Findings: Differences $(\mathrm{p}<0.05)$ were observed in the gestation rates, that is $76 \%$ and $45.5 \%$ for animals of the treatments 1 and 2 , respectively. The serum concentrations of $\mathrm{P} 4$ were $1.34 \pm 0.49$ and $2.16 \pm 1.17$ for the treatments 1 and 2 respectively $(\mathrm{p}<0.01)$. A low correlation $(\mathrm{r}=0.45)$ was observed between $\mathrm{P} 4$ levels and the presentation of pregnancy. Application: Cows with dominant follicles $<13 \mathrm{~mm}$ in diameter at the time of application E2 have a higher gestation rate even with lower production of P4.
\end{abstract}

Keywords: Cows, Gestation, Reproductive Biotechnology, Reproduction

\section{Introduction}

In the rural properties, the continuous improvement of the production and productivity is a result from the adoption of appropriate technologies. So, this increase of the productivity can compensate the fall of the prices received by producers $^{1}$ which usually discourages the production. In this context, the incorporation of biotechniques such as the conventional Artificial Insemination (IA), the Artificial Insemination in Fixed Time (IATF), the in Vitro Production (PIV) of embryos and the Transfer of Embryos (TE) are mentioned.

In this context, many hormonal protocols were developed for better understanding the physiology of the ovarian follicular growth, as well as the need for solving the problem of the low service rate due to the inefficiency

${ }^{*}$ Author for correspondence 
of the estrum identification². Among those protocols, some seek to synchronize the ovulation and manifestation of the estrum behavior with the use of prostaglandins $\left(\mathrm{PGF}_{2 \alpha}\right)$ and other hormones.

The limited success of the IATF programs in cows under lactation conditions was partially related to the development stages of the follicular waves at the moment of the application of $\mathrm{PGF}_{2 \alpha}{ }^{3}$. In addition, several studies have been indicating the probability of the conception to be related with the diameter of the ovulatory follicle $e^{4,5}$.

According to ${ }^{6}$, low conception rates are obtained in milky cattle until the moment, that is, below 35\% in several countries. Nowadays, what is noticed in the national milky livestock is the indiscriminate use of hormones and protocols, sometimes without any technical follow-up. In this context, the attendance of the treated animals and the knowledge of the physiology, ovarian function and size of the follicles are extremely important for the obtainment of better results. Therefore, the absence of this attendance can be a decisive factor in the results, which have not been satisfactory; not surpassing $50 \%$ of the gestation rate, according to several scientific works accomplished in Brazil and revised by ${ }^{6}$.

The present study was carried to evaluate the effect of the follicular size (diameter) at the moment of the estradiol application $\left(\mathrm{E}_{2}\right)$ upon gestation rate, by using the hormonal protocol PGF $\mathrm{P}_{2 \alpha}-\mathrm{E}_{2}$ - IATF in crossbred cows cycling.

\section{Materials and Methods}

\subsection{Animals, IATF Protocol, Treatments and Pregnancy Diagnosis}

The experiment was conducted in the Universidade Federal de Viçosa - Florestal Campus - Minas Gerais, at coordinates $19^{\circ} 53^{\prime} 12^{\prime \prime}$ South and $44^{\circ} 25^{\prime} 56^{\prime \prime}$. The project concerning to the present experiment was subjected to the Committee of Ethics of the Department of Veterinary Medicine, as being approved on March 05 2011. In the present experiment, 47 crossbred cows Bos Taurus $\mathrm{x}$ indicus in nursing were used, as presenting cyclical luteal ovarian activity and with corporal condition score $\geq 3.0$ based on the criteria used by ${ }^{6}$. The animals were maintained under pasture (Brachiaria decumbens), with mineral supplementation during the rainy period and with maize silage during the dry period, besides concentrate and water supplied ad libitum in both periods.
Initially, the cyclical state of each animal was determined through transrectal ultrasonographic examination (CHISON D600 VET, lineal multifrequency transducer adjusted to $7.0 \mathrm{MHz}$ ) for identification of the ovarian structures. Additionally, two blood collects were accomplished for determination of the serum progesterone concentration by the Radioimmunoassay method, with eight-day intervals between the collects. Only the animals presenting no pathologies in the genital organs were used.

At 24 hours before receiving the first hormonal application of $\mathrm{PGF}_{2 \alpha}$, the cows were submitted to ultrasonographic examination by transrectal via in order to measure the diameter of the largest follicle. After the cyclicity was confirmed and the presence of a corpus luteum was detected by palpation, other blood collect was accomplished for analysis of the serum progesterone concentration. Later, the cows were given the first hormonal application on the morning, with $150 \mu \mathrm{g}$ of the synthetic analogue of $\mathrm{PGF}_{2 \alpha}$ (D+chloprostenol, Luteolitic Veteglan ${ }^{\circledR}$ Hertape Calier), by intramuscular via. Following, they were again submitted to ultrasonographic examination by transrectal via, for mensuration of the dominant follicular diameter and confirmation that this one was not on atresia. When the diameter of this follicle was inferior to the first ultrasonographic evaluation, the cows were not given the hormonal application, and an approximate six-day period was awaited for a new following up of the follicular dynamics.

After 24 hours from application of $\mathrm{PGF}_{2 \alpha}$, the cows were given a treatment on the morning with $2 \mathrm{mg}$ of estradiol (Estradiol benzoate, RIC-BE ${ }^{\circledR}$, Tecnopec Ltda) intramuscular via. Then, they were again evaluated through an ultrasonographic examination for mensuration of the dominant follicle diameter, and later they were divided into two treatments: treatment 1 (cows with dominant follicle with diameter $<13 \mathrm{~mm}$ ) and treatment 2 (cows with dominant follicle with diameter $\geq 13 \mathrm{~mm}$ ).

From the application of prostaglandin, all cows were maintained under visual observation for $30 \mathrm{~min}$ utes, twice a day (on the beginning of the morning and final afternoon), in order to observe the estrus with the aid of one ruffian. After 48 hours from application of the estradiol, the cows were artificially inseminated. However, those presenting the estrus in advance were inseminated at 12 hours after its manifestation. Doses of semen from the bulls with proven fertility were used, whereas the inseminations were accomplished by a single inseminator. 
At ten days after the accomplishment of IATF, all cows were submitted to other blood collect for quantification of the serum progesterone concentration. The blood was obtained by puncture of the coccygeal artery or vein, by using a $5 \mathrm{~mL}$ vacuum tube for collection of the blood and coupled to a vacuum collection needle. Approximately five $\mathrm{mL}$ of blood were punctured and the serum was obtained after centrifugation at $1.700 \mathrm{G}$ for $10 \mathrm{~min}$, by using a Baby Centrifuge $\mathrm{I}$ Model 206 BL. The obtained serum was pipetted and transferred to a plastic $2 \mathrm{~mL}$ tube (Eppendorf) properly identified. The tubes containing the serum were stored at $-20^{\circ} \mathrm{C}$ until determination of the serum progesterone concentration.

The progesterone dosages were accomplished by the Radioimmunoassay technique (RIA - $\mathrm{I}^{125}$ ) in the Laboratory of Animal Reproduction of the Universidade Estadual Paulista "Júlio de Mesquita Filho" - UNESP Campus de Botucatu, by using commercial kits for determination of progesterone. The progesterone concentration starting from $1.0 \mathrm{ng} / \mathrm{mL}$ was considered as luteal activity, according to ${ }^{z}$.

The gestation diagnosis was accomplished at 30 and 100 days after IATF through ultrasonography via transrectum. The interpretation of the ultrasound images for diagnosis of the gestation was based on the criteria used by ${ }^{-}$, where are included: 1 . presence of a one fetus, 2 . presence of an amniotic liquid, and 3. detectable heartbeat.

\subsection{Statistical Analysis}

The quantitative variables were subjected to the tests of Normality (Lilliefors) and Homocedacity (Cochran) and later to variance analysis. The Medias were compared, by using the F-test at 5\% Probability level. When the data did not attend the normality and homocedascity premises even after the appropriate transformations, the data were subjected to Wilcoxon nonparametric test. The Pearson correlation test was applied between the progesterone serum concentration on the 10th day after IA and at the presence or not of gestation. The dichotomous qualitative variable "gestation rate" was compared in contingency table and analyzed by the qui-square test at 5\% probability level, using the $\mathrm{R}^{\circledR}$ software (R Development Core Team, 2008).

\section{Results and Discussion}

The cyclicity of all cows was initially confirmed through two blood collects at eight-day interval. The values of the serum concentration of $\mathrm{P} 4(\mathrm{ng} / \mathrm{mL})$ presented no differences ( $p>0.05$ ) among samples, as presenting averages of $1.20 \pm 0.40$ and $1.29 \pm 0.51 \mathrm{ng} / \mathrm{mL}$ of serum at the first and second collects, respectively. Since the luteal activity is considered from $1.0 \mathrm{ng} / \mathrm{mL}$ of serum ${ }^{7}$, the cows showed to have this activity. Therefore, they are apt to be used in the experiment.

The protocols that use $\mathrm{E}_{2}$, such as the one used in the present study, are important because the increase of the $\mathrm{E}_{2}$ circulation before IA rather increases the expression of the estrus ${ }^{2}$. According to those authors, $\mathrm{E}_{2}$ in proestrus contributes either to the increased endometrium thickness before IA and to the increased embryonic survival. However, this thickness was not measured in the present study. The time of the estrus presentation after the application of $\mathrm{PGF}_{2 \alpha}$ presented no differences ( $\left.\mathrm{p}>0.05\right)$, since $24(36 \%)$ presented the estrus until 48 hours after PGF $_{2 \alpha}$ and $52(45.5 \%)$ presented the estrus up to 60 hours after $\mathrm{PGF}_{2 \alpha}$ in the animals of the treatments 1 and 2, respectively (Table 1). The ovulation time after application of $\mathrm{PGF}_{2 \alpha}$ varies from two to seven days, as depending on the size of the follicle at the moment of application. In other words, if the follicle size is lower, it will require more time to grow and ovulate ${ }^{6}$. However, because the cows of the present study received an additional $\mathrm{E}_{2}$ application after $\mathrm{PGF}_{2 \alpha}$ in order the ovulation to be synchronized, it was not possible to detect this difference.

Table 1. Percentage of the animals presenting the estrus at 48 or 60 hours after application of $\mathrm{PGF}_{2 \alpha}$ in cows with different follicular categories

\begin{tabular}{|l|c|c|c|c|l|}
\hline \multirow{2}{*}{ Treatment } & \multicolumn{2}{|l|}{ Estrus 48h } & \multicolumn{2}{l|}{ Estrus 60h } & \multirow{2}{*}{$\begin{array}{l}\text { Total } \\
\text { animals }\end{array}$} \\
\cline { 2 - 5 } & $\mathbf{N}$ & $\mathbf{\%}$ & $\mathbf{N}$ & $\mathbf{\%}$ & 25 \\
\hline$<\mathbf{1 3 m m}$ & 6 & $24.0^{\mathrm{a}}$ & 13 & $52.0^{\mathrm{a}}$ & 22 \\
\hline$\geq \mathbf{1 3 \mathbf { m m }}$ & 8 & $36.4^{\mathrm{a}}$ & 10 & $45.4^{\mathrm{a}}$ & 22 \\
\hline
\end{tabular}

There were no differences $(\mathrm{p}>0.05)$ between treatments, by the qui-square test 
The gestation rate of the animals of the treatment 1 was higher $(76 \%)$ than the group of the treatment 2 $(45.5 \%)$, as occurring a difference in the results $(\mathrm{p}<0.05)$ as shown in Table 2 . These results were similar to those found by ${ }^{10}$, who obtained better results for ovulatory follicles with diameter between 10.1 to $14.1 \mathrm{~mm}$, as resulting into gestation rate of $76 \%$ at 30 days after IA. They also found a gestation rate of $57 \%$ for follicles between 14.2 and $15.1 \mathrm{~mm}$ in 84 heifers, only with the use of two PGF applications at 11-days interval, and the observed estrus.

Table 2. Gestation rate in cows with different follicular categories

\begin{tabular}{|l|c|c|c|}
\hline \multirow{2}{*}{ Treatment } & \multicolumn{2}{|l|}{ Pregnant } & \multirow{2}{*}{ Total animals } \\
\cline { 2 - 3 } & $\mathbf{N}$ & $\mathbf{\%}$ & \\
\hline$<\mathbf{1 3} \mathbf{m m}$ & 19 & $76.0^{\mathrm{a}}$ & 25 \\
\hline$\geq \mathbf{1 3} \mathbf{m m}$ & 10 & $45.5^{\mathrm{b}}$ & 22 \\
\hline
\end{tabular}

There was difference $(\mathrm{p}<0.05)$ between treatments, by the qui-square test

In this study, the moment of the follicle mensurations differa from ${ }^{11}$ who made the mensurations in the day of IATF. Besides, they obtained better gestation rate $(\mathrm{p}<0.05)$ in cows with ovulatory follicles with diameter starting from $11.1 \mathrm{~mm}(57.9 \%)$ and $>14 \mathrm{~mm}(63.3 \%)$, as compared with ovulatory follicles of $7.5-11 \mathrm{~mm}$ (46.6\%). Therefore, the precociously synchronized follicles do not present satisfactory results. Those authors suggested the follicles with $11.1 \mathrm{~mm}$ diameter or more to be selected for the ovulation synchronization. In the present study, the category obtaining higher gestation rate was $<13 \mathrm{~mm}$ in the day of the $\mathrm{E}_{2}$ application (before IA), what probably would make possible a larger follicular diameter at the IA moment. However, this condition was not evaluated.

In other study in which the follicle was measured on IATF day, therefore different from the present study, $100 \mu \mathrm{g}$ of GnRH were used in bovine with FD of 11 and $13 \mathrm{~mm}$ at two days after application of $\mathrm{PGF}_{2 \alpha}$, and result the conception rates of $4.4 \%$ and $57.4 \%$ of the animals' respectively ${ }^{12}$. Therefore, an expressive alteration in the results with a difference of $2 \mathrm{~mm}$ among the follicles.

The results agree with those obtained by some authors, who report the success of the gestation in heifers to be larger with pre-ovulatory follicle with diameter around $12.8 \mathrm{~mm}$ than with follicles that are smaller than $10.5 \mathrm{~mm}$ or larger than $15.7 \mathrm{~mm}^{\underline{5}}$. When using a different protocol, those authors submitted the beef cattle beef cow either to IATF protocol so-known Co-Synch (day $0 \mathrm{GnRH}$, day $7 \mathrm{PGF}_{2 \alpha^{\prime}}$, day $9 \mathrm{GnRH}$ and IA or to insemination) with detection of the estrus. On the contrary, they verified that the embryonic/fetal survival rate was reduced when follicles lower than $11 \mathrm{~mm}$ were induced to ovulation with $\mathrm{GnRH}$ but was not reduced when they ovulated spontaneously ${ }^{12}$. However, the follicle categories evaluated by those authors are not similar to the ones evaluated in the present experiment.

It is probable that the lowest gestation rate verified in the animals with dominant follicles $\geq 13 \mathrm{~mm}$ occurred due to the possibility for some follicles to be under dominance during extensive period before the LH peak. Therefore, they are so-called persistent follicles, which reduce the conception rate, when compared with lower pre-ovulatory follicles, according to ${ }^{13}$. Those authors suggest that one of the causes could be a sub-luteal P4 concentration during $\mathrm{CE}$, as increasing the $\mathrm{LH}$ frequency. So, this fact can induce the premature new beginning of the meiosis in the oocyte, as reducing the fertility due to ME before the stage of 16 cells. In addition, other scientific work associates the decrease of the fertility to ovulations of persistent and large follicles ${ }^{\underline{14}}$. In addition, this situation was also associated to a decreased fertility in natural estrus of dairy cows ${ }^{15,16}$.

There were no differences $(\mathrm{p}>0.05)$ in the gestation rate (68\%), in animals with Service Period (PS) from 40 to 70 days, when compared to animals with PS from 71 to 225 days, respectively (Table 3 ). The voluntary expectation period in the study totalized 30 days, that is the time required for occurrence of the involution of the feminine genital organs and the animal can recover physical and physically to receive a new gestation. From this period, if the cows present a satisfactory corporal condition, they will be ready to be inseminated, and if they become pregnant corresponds to the service period ${ }^{6}$. According to the results, it is suggested that the increased service period did not interfere into gestation rate of the cows.

Table 3. Service period (days) and gestation rate in cows submitted to ovulation synchronization for IATF

\begin{tabular}{|l|c|c|c|}
\hline \multirow{2}{*}{$\begin{array}{l}\text { Service } \\
\text { period }\end{array}$} & \multicolumn{2}{|l|}{ Pregnant } & \multirow{2}{*}{ Total animals } \\
\cline { 2 - 3 } & $\mathbf{N}$ & $\mathbf{\%}$ & \\
\hline $\mathbf{4 0}-\mathbf{7 0}$ & 17 & 68.0 & 25 \\
\hline $\mathbf{7 1}-\mathbf{2 2 5}$ & 12 & 54.5 & 22 \\
\hline
\end{tabular}

There were no differences ( $p>0.05)$ for average values of the follicular diameter at the moment of the $\mathrm{PGF}_{2 a}$ 
application, at the moment of the $\mathrm{E}_{2}$ application and between the growth of the same ones (Table 4).

Table 4. Mean values and standard deviations for different follicular categories $(\mathrm{mm})$ at the moment of application of the $\mathrm{PGF}_{2 a}$ and $\mathrm{E}_{2}$ and the difference between them in cows submitted to synchronization of the ovulation for IATF

\begin{tabular}{|c|c|c|c|c|}
\hline Treatment & DF-PGF $_{2 \alpha}$ & DF-E $_{2}$ & DDF & $\begin{array}{c}\text { Total } \\
\text { animals }\end{array}$ \\
\hline$<\mathbf{1 3 m m}$ & $9.58 \pm 1.58$ & $10.96 \pm 1.56$ & $1.39 \pm 0.72$ & 25 \\
\hline$\geq \mathbf{1 3 m m}$ & $13.38 \pm 2.53$ & $15.62 \pm 2.41$ & $2.25 \pm 1.21$ & 22 \\
\hline Total & $\mathbf{1 1 . 3 5} \pm \mathbf{2 . 8 1}$ & $\mathbf{1 3 . 1 4} \pm \mathbf{3 . 0 8}$ & $\mathbf{1 . 7 9} \pm \mathbf{1 . 0 6}$ & $\mathbf{4 7}$ \\
\hline
\end{tabular}

DF-PGF ${ }_{2 \alpha}=$ diameter of the Dominant Follicle (FD) at the moment of the $\mathrm{PGF}_{2 a}$ application; $\mathrm{DF}-\mathrm{E}_{2}=\mathrm{FD}$ diameter at the moment of the $\mathrm{E}_{2}$ application; $\mathrm{DDF}=$ difference between DF- $\mathrm{E}_{2}$ and DF-PGF ${ }_{2 a}$

A low correlation $(\mathrm{r}=0.45)$ between the $\mathrm{P} 4$ concentration on the tenth day after IA and the presence of gestation was found in this study. However, authors revised by ${ }^{6}$ report that the $\mathrm{P} 4$ concentration from 10 to 18 days after the estrus is generally higher in pregnant cows than in those under cycle, therefore suggesting the production of luteotropic factors by embryo ${ }^{17}$ also report the maintenance of the gestation during five to nine weeks after IA to be positively related with the serum concentration of $\mathrm{P} 4$ and $\mathrm{E}_{2}$.

On the contrary, however ${ }^{10}$ showed a positive association between the embryonic survival rate on the 30th day and the P4 concentration on the 7th day after IA. However, similar to the present work, gestations with lower serum concentration of $\mathrm{P} 4(<2.0 \mathrm{ng} / \mathrm{mL})$ on the days 20 to 22 after

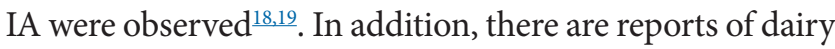
cows with less than $1 \mathrm{ng} / \mathrm{mL}$ on the 5 th week of gestation, despite presenting a normal-sized CL and viable embryo ${ }^{17}$. Similar values were found in other studies as suggesting that the minimum P4 concentration to maintain the embryonic survival could be lower than $1 \mathrm{ng} / \mathrm{mL}$ of plasma ${ }^{20}$.

Also, contrarily to the accomplished experiment ${ }^{21}$ found positive correlation between the progesterone concentration on the day of the involution and the subsequent gestation rate, in a study with 223 receivers of bovine embryos that is the day corresponding to the eighth day after ovulation. In a similar scientific work, those aspects were compared between cows and receiving heifers after transfer, as verifying the low serum concentration of the plasmatic $\mathrm{P} 4$ on the 7 th day in pregnancy cows to nega- tively affect the embryonic survival. However, this effect on heifers is less evident ${ }^{22}$. Under those conditions, the pregnancy cows have larger possibility to suffer embryonic death than heifers $(\mathrm{p}<0.1)$, mainly in the case of frozen embryos. Those authors suggested this to be associated to low CL competence on the seventh day $(3.03 \pm 0.08$ and $2.71 \pm 0.08 \mathrm{ng} / \mathrm{mL}$ for heifers and cows, respectively). However, those values are superior to the ones found in the present study, even in cows from which the dominant follicle was higher or equal to $13 \mathrm{~mm}$ (treatment 2), in which a higher concentration of $\mathrm{P} 4$ was observed. In addition, lower $\mathrm{P} 4$ concentrations (treatment 1) (Table 5) did not endanger the gestation rate.

Table 5. Average values and standard deviations for serum progesterone concentration $(\mathrm{ng} / \mathrm{mL})$ at the moment of the application of $\mathrm{PGF}_{2 \alpha}\left(\mathrm{P}_{3}\right)$ and on the $10^{\circ}$ day after Artificial insemination $\left(\mathrm{P}_{4}\right)$ in cows with different follicular categories, which were submitted to synchronization of the ovulation for IATF

\begin{tabular}{|c|c|c|c|}
\hline Treatment & $\mathbf{P 4}_{\mathbf{3}}(\mathbf{n g} / \mathbf{m L})$ & $\mathbf{P 4}_{\mathbf{4}}(\mathbf{n g} / \mathbf{m L})$ & Total animals \\
\hline$<\mathbf{1 3 m m}$ & $1.23 \pm 1.23^{\mathrm{a}}$ & $1.34 \pm 0.49^{\mathrm{a}}$ & 21 \\
\hline$\geq \mathbf{1 3} \mathbf{m m}$ & $1.70 \pm 1.24^{\mathrm{a}}$ & $2.16 \pm 1.17^{\mathrm{b}}$ & 20 \\
\hline Total & $\mathbf{1 . 4 6} \pm \mathbf{1 . 2 4}$ & $\mathbf{1 . 7 4} \pm \mathbf{0 . 9 7}$ & $\mathbf{4 1}$ \\
\hline
\end{tabular}

Values with different letters superscribed in the same column indicate differences $(\mathrm{p}<0.01)$ by Wilcoxon. Test. $\mathrm{P}_{3}=$ serum progesterone concentration at the moment of the application of $\mathrm{PGF}_{2 \alpha} ; \mathrm{P}_{4}=$ progesterone concentration on the tenth day after Artificial Insemination

According to ${ }^{23}$, the action of the progesterone is important not only during gestation, but also at the moments preceding fecundation, as preparing the uterine environment for the concept. The regulation of the growth and the development of the embryo (blastocyst prolongation) are added to those aspects ${ }^{22}$. However, those authors did not mention the minimum $\mathrm{P} 4$ concentrations required for those effects. Thus, the low $\mathrm{P} 4$ concentrations do not mean that the same effects did not occur in the cows of the present work.

On the 10th day after IA, there were differences $(p<0.01)$ for the serum P4 concentration between animals of the treatment 1 and treatment 2 (Table 5). These aspects are similar to those found $\mathrm{by}^{24}$, who evaluated the effects of the ovulatory potential of the follicle in induction of the estrus. Those authors concluded that, during the ovulatory cycle, the CL size and the P4 plasmatic concentration were higher in the group of cows synchronized 
with mature FD than young FDs. However, the resulting CL size was not measured in the present study. From these results, it is suggested that the size of the formed $\mathrm{CL}$ and the plasmatic P4 concentration are directly associated with the FD diameter at the moment of the ovulation. According to ${ }^{6}$, the plasmatic $\mathrm{P} 4$ concentration is more related with the CL function than with the size. Cows with larger follicles and short follicular phase rather produce CLs with higher capacity for production of P4, although the quality of the pre-ovulatory follicle in itself (a decisive factor of this quality is the vascularity degree) is decisive for the subsequent luteal function.

In other study ${ }^{25}$ reduced the size of the ovulatory follicle by follicular aspiration in 52 pregnant cows which were synchronized. They concluded there were reduction in the resulting CL size, P4 concentration and gestation rate. According to those authors, this condition might have happened due to endangerment of the oocyte development competence. In addition, evaluations of the oocytes of persistent follicles revealed the rupture of the germinative vesicle occurred prematurely, before ovulation and this probably caused the reduction of the fertility ${ }^{26}$. Therefore, it is suggested that either categories of the small follicles and large follicles can affect the oocytes somehow.

Even plasmatic concentrations that are lower than $1 \mathrm{ng} / \mathrm{mL}$ of progesterone are detected at the beginning of gestations $s^{17}$, values that approach to the ones found in the cows with dominant follicle lower than $13 \mathrm{~mm}$ (treatment 1) in the present study.

The results of the countless scientific works on the efficiency in synchronization of the ovulation of either very large or very small follicles rather suggest an optimum category to synchronize the ovulation to be the medium follicles (between $>10 \mathrm{~mm}$ and $\leq 13 \mathrm{~mm}$ ). Among the important aspects for the embryonic survival, the following are distinguished: the enough $\mathrm{P} 4$ production after IA; the appropriate uterine environment due to several factors and the oocyte able to be ovulated.

Reinforcing the objective of the present study, in recent revision carried out by ${ }^{27}$, it is emphasized that the optimization of the ideal size of the ovulatory follicle has been important objective of the researches in reproductive programs, particularly in those using the synchronization of the ovulation. Those authors also mention that the chosen hormonal treatment and the duration of the follicle development are important components in optimization of the fertility in the IATF programs. According to the authors, these aspects can have impact on fertility, as altering the function of the oocyte, the number and function of the cells of the granulosa and teca, the uterine atmosphere, besides other reproductive functions.

The results found in the present experiment emphasize the importance of the previous evaluation of the ovarian condition, through ultrasonography accomplished before application of protocols for IATF. These results constitute important subsidies for improvement of the results with IATF in the works under field conditions and, consequently, a larger diffusion of this technology.

\section{Conclusions}

At the moment of the estradiol application, the follicular diameter has influence on fertility of the dairy cows, and the follicles from which the diameter is lower than $13 \mathrm{~mm}$ present better results than those $\geq 13 \mathrm{~mm}$. The follicles with diameter $\geq 13 \mathrm{~mm}$ form corpus luteum that produce higher amount of progesterone after the artificial insemination. However, no increment occurs in the gestation rate.

\section{References}

1. Carvalho G, Martins P. Leite: Por que o preço disparou? Agroanalysis. 2007; 33(8):25-26.

2. Barros C, Nogueira M. Embryo transfer in Bos indicus cattle, Theriogenology. 2001; 56(9):1483-96. Crossref.

3. Macmillan K, Segwagwe B, Pino C. Association between manipulation of patterns of follicular development and fertility in cattle, Animal Reproduction Science. 2003; 78(34):327-44. Crossref.

4. Lopes A, Butle, S, Gilbert R, Butler W. Relationship of preovulatory follicle size, estradiol concentrations and season to pregnancy outcome in dairy cows, Animal Reproduction Science. 2007; 99(1-2):34-43. Crossref. PMid:16777360.

5. Perry G, Smith M, Roberts A, MacNeil M, Geary T. Relationship between size of the ovulatory follicle and pregnancy success in beef heifers, Journal of Animal Science. 2007; 85(3):684-89. Crossref. PMid:17060416.

6. Ferreira A. Reprodução da Fêmea Bovina: Fisiologia aplicada e problemas mais comuns (causas e tratamentos). Juiz de Fora: Editar Editora; 2010. p. 1-420.

7. Gonçalves P, Figueiredo J, Freitas, F. Biotécnicas Aplicadas à Reprodução Animal. Controle do Estro e da Ovulação em Bovinos e Ovinos. São Paulo: Varela Editora e Livraria Ltda. 2002; p. 25-55.

8. Fricke P, Ricci A, Giordano J, Carvalho P. Methods for and implementation of pregnancy diagnosis in dairy cows, Veterinary Clinics of North America. 2016; 32(1):165-80. Crossref. 
9. Glissant A, Demouzon J, Frydman R. Ultrasound study of the endometrium during in vitro fertilization cycles, Fertility and Sterility. 1985; 44(6):786-90. Crossref.

10. Lynch C, Kenny D, Childs S, Diskin M. The relationship between periovulatory endocrine and follicular activity on corpus luteum size, function, and subsequent embryo survival, Theriogenology. 2010; 73(2):190-98. Crossref. PMid:19932503.

11. Sá Filho M, Crespilho A, Santos J, Perry G, Baruselli P. Ovarian follicle diameter at timed insemination and estrous response influence likelihood of ovulation and pregnancy after estrous synchronization with progesterone or progestin-based protocols in suckled Bos indicus cows, Animal Reproduction Science. 2010; 120(1-4):23-30. Crossref. PMid: 20395079.

12. Perry G, Smith M, Roberts A, MacNeil M, Geary T. Relationship between size of the ovulatory follicle and pregnancy success in beef heifers, Journal of Animal Science. 2007; 85(3):684-89. Crossref. PMid:17060416.

13. Santos J, Thatcher W, Chebel R, Cerri R, Galvao A. The effect of embryonic death rates in cattle on the efficacy of estrus synchronization programs, Animal Reproduction Science. 2004; 82-83:513-35. Crossref. PMid:15271477.

14. Savio J, Thatcher W, Morris G, Entwistle K, Drost M, Mattiacci M. Effects of induction of low plasma progesterone concentrations with a progesterone-releasing intravaginal device on follicular turnover and fertility in cattle, Journal of Reproduction and Fertility. 1993; 98(1):77-84. Crossref. PMid: 8345482.

15. Lopez H, Caraviello D, Satter L, Fricke P, Wiltbank M. Relationship between level of milk production and multiple ovulations in lactating dairy cows, Journal of Dairy Science. 2005; 88(8):2783-93. Crossref.

16. Wiltbank M, Lopez H, Sartori R, Sangsritavong S, Gumen A. Changes in reproductive physiology of lactating dairy cows due to elevated steroid metabolism, Theriogenology. 2006; 65(1):17-29. Crossref. PMid: 16290258.

17. Starbuck M, Dailey R, Inskeep E. Factors affecting retention of early pregnancy in dairy cattle, Animal Reproduction Science 2004; 84(1-2):27-39. Crossref. PMid: 15302385.
18. Screenan J, Diskin M. Mortality in the cow. In: Screenan JM, Diskin MG, editors. Embryonic Mortality in Farm Animals. Dordrecht: The Netherlands: Martinus Nijhoff Publishers; 1986. p. 1-12. Crossref.

19. Hasler J, Mccauley A, Lathrop W, Foote R. Effect of donor-embryo-recipient interactions on pregnancy rate in a large-scale bovine embryo transfer program, Theriogenology. 1987; 27(1):139-68. Crossref.

20. Erb R, Estergreen V, Gomes W, Plotka E, Frost O. Progestin levels in corpora lutea and progesterone in ovarian venous and jugular vein blood plasma of the pregnant bovine, Journal of Dairy Science. 1968; 51(3):401-10. Crossref.

21. Remsem L, Roussel J, Karihaloo A. Pregnancy rates relating to plasma progesterone levels in recipient heifers at day of transfer, Theriogenology. 1982; 8(3):365-72. Crossref.

22. Chagas E Silva J, Lopes Da Costa L, Robalo Silva J. Plasma progesterone profiles and factors affecting embryofetal mortality following embryo transfer in dairy cattle, Theriogenology. 2002; 58(1):51-59. Crossref.

23. Binelli M, Thatcher W, Mattos R, Baruselli P. Antiluteolytic strategies to improve fertility in cattle, Theriogenology. 2001; 56(9):1451-63. Crossref.

24. Burke C, Mussard M, Grum D, Day M. Effects of maturity of the potential ovulatory follicle on induction of oestrus and ovulation in cattle with oestradiol benzoate, Animal Reproduction Science. 2001; 66(3-4):161-74. Crossref.

25. Vasconcelos J, Sartori R, Oliveira H, Guenther J, Wiltbank M. 2001. Reduction in size of the ovulatory follicle reduces subsequent luteal size and pregnancy rate, Theriogenology. 2001; 56(2):307-14. Crossref.

26. Mihm M, Curran N, Hyttel P, Knight P, Boland M, Roche J. Effect of dominant follicle persistence on follicular fluid oestradiol and inhibin and on oocyte maturation in heifers, Journal of Reproduction and Fertility. 1999; 116(2):293-304. Crossref. PMid: 10615254.

27. Wiltbank M, Sartori R, Herlihy M, Vasconcelos J, Nascimento A, Souza A, Ayres H, Cunha A, Keskin A, Guenther J, Gumen A. Managing the dominant follicle in lactating dairy cows, Theriogenology. 2011; 76(9):1568-82. Crossref. PMid: 21958644. 